УДК 597.556.31(262.5):591.13

doi: 10.31140/j.vestnikib.2020.1(212).1

\title{
СОВРЕМЕННЫЕ СВЕДЕНИЯ О ПИЩЕВОМ СПЕКТРЕ ЧЕРНОМОРСКОЙ СКОРПЕНЫ SCORPAENA PORCUS LINNAEUS, 1758
}

\author{
В.А. Тимофеев ${ }^{1}$, Н.С. Кузьминова ${ }^{1,2}$, Л.В. Бондаренко ${ }^{1}$, Г.В. Куликов ${ }^{2}$ \\ 1 Институт биологии южных морей им. А.О. Ковалевского Российской академии наук, Севастополь \\ ${ }^{2}$ Севастопольский Центр эколого-натуралистического творчества учащейся молодежи, Севастополь \\ E-mail: tamplier74@mail.ru
}

\begin{abstract}
Аннотация. Изучен пищевой спектр морского ерша (скорпены) - Scorpaena porcus Linnaeus, 1758 на особях, отловленных в Балаклавской, Стрелецкой, Севастопольской и Карантинной бухтах г. Севастополя. Зимой, весной и осенью в пищевом комке S. porcus преобладают Malacostraca (15, 19 и $14 \%$ соответственно), летом - Pisces (14\%). В 2017-2018 гг. по сравнению с данными прошлого века и начала нынешнего столетия (до 2014 г. включительно) изменилось пищевое разнообразие объектов питания S. porcus. Переход ерша на питание более мелкими видами Malacostraca произошёл из-за резкого сокращения численности Decapoda по сравнению с прошлым веком.
\end{abstract}

Ключевые слова: морской ерш, питание, Черное море, Севастополь

\section{Введение}

Питание рыб - один из основных физиологических процессов, определяющих их общую жизнедеятельность на всех стадиях жизненного цикла.

Доля современных публикаций, посвященных питанию представителей черноморской ихтиофауны, по-прежнему мала. В 2011 г. нами была начата и по настоящее время продолжается работа по изучению трофики рыб на примере морского ерша (скорпены) - Scorpaena porcus Linnaeus, 1758. Это важно из-за ценности данного вида как одного из конечных звеньев пищевой цепи, использования ерша в качестве вторичного объекта промысла, а главное - его доступности для анализа на протяжении годового цикла и хорошей изученности биологических особенностей (Световидов, 1964).

Известно, что спектр питания ерша меняется в зависимости от места обитания, возраста и сезона. В местах с различными экологическими условиями состав пищи Scorpaena porcus различен. Это связано с тем, что виду свойственно отсутствие избирательной пищевой способности в течение года. В середине прошлого века значительная доля встречаемости организмов в пище ерша, обитающего в акваториях Севастополя, приходилась на рыб и Decapoda (десятиногих ракообразных). При этом мелкие (до 70 мм) особи ерша питались в основном представителями Amphipoda и Isopoda. Ранее отмечено, что в течение года ерши, обитающие на площади в 1 га, потребляли в пищу более 45 кг различных организмов. Из этого количества около $48 \%$ составляли Decapoda, $44 \%$ - Pisces, $4 \%$ - Schisopoda (coвp. Mysida), $2 \%$ - Isopoda, по $1 \%$ - Amphipoda и Polychaeta (Фортунатова, 1949).
Высшие ракообразные и рыбы - главные компоненты в питании ерша. Современная фауна высших ракообразных Азово-Черноморского бассейна неоднородна и состоит из 225 видов. Таксономический состав Malacostraca, обитающих в акваториях Крымского побережья, насчитывает около 140 видов, из них в бухтах Севастополя более 90 (Ревков, 2003, 2008; Копий, 2007; Зообентос ..., 2009; Тимофеев, 2016; Макрозообентос ..., 2018). По данным Е.Д. Васильевой (2007), в Черном море и солоноватых водах Азовского моря насчитывается 176 видов рыб, относящихся $к 57$ семействам и 22 отрядам. В результате многолетних мониторинговых исследований и анализа современных данных литературы установлено, что в акватории Севастополя, включающей шесть наиболее крупных бухт и открытую прибрежную зону между мысами Толстый и Айя, за последние 30 лет отмечены 120 видов рыб из 81 рода, принадлежащих к 49 семействам (Болтачев, 2014). Ихтиологический материал, собранный в период 1996-2011 гг., показал наличие в указанном районе 108 видов, среди которых 22 встречены впервые (Болтачев, 2012).

Последние наблюдения за питанием $S$. porcus свидетельствуют о происходящих изменениях в пищевом спектре этого вида, связанных с флуктуациями как видового состава гидробионтов черноморской экосистемы, так и гидрохимического статуса акваторий (Кузьминова, 2017).

\section{Материалы и методы}

Объект исследования - взрослые экземпляры S. porcus. Отлов рыб проводили в бухтах г. Севастополя (Балаклавская, Стрелецкая, Севастопольская и Карантинная) с помощью донных ловушек (размер ячеи 12 мм) в 2017-2018 гг. преимущественно в теплый период года. 
Биоанализ рыб включал промеры стандартной длины (Sl, cм), определение пола, стадии зрелости, а также массы рыбы, тушки, печени. Возраст рыб устанавливали по отолитам, расчет индекса печени (ИП) и упитанности проводили по методам, описанным ранее (Правдин, 1966; Шварц, 1968).

Степень наполнения желудков (и объекты питания) оценивали у 270 особей по шестибалльной шкале: 0 - желудок пустой, 1 - наполнение желудка очень слабое, видны слизь и слабые следы пищи, 2 - наполнение желудка слабое, 3 наполнение желудка среднее, 4 - наполнение желудка хорошее, 5 - желудок растянут, пища просвечивает через его стенки (Методы ..., 2010).

В исследованиях таксономического состава Маlacostraca использованы данные, полученные в результате бентосных работ в период с 2004 по 2018 г. В процессе изучения обследованы акватории вышеназванных бухт г. Севастополя в диапазоне глубин от 0 до 30 м. Сбор материала проводили ручным дночерпателем $\left(\mathrm{S}=0.04 \mathrm{~m}^{2}\right.$, глубина менее $10 \mathrm{M)}$ или дночерпателем Петерсена $\left(\mathrm{S}=0.04 \mathrm{~m}^{2}\right.$, глубина более $\left.10 \mathrm{м}\right)$ в двух повторностях. При промывке проб использована система сит с минимальным диаметром ячеи фильтрации 0.5 мм. Для отбора эпифауны с камней делали смывы через сито с диаметром ячеи 0.5 мм, а для сбора бентосных проб в обрастаниях естественных твердых субстратов использовали рамку $\left(\mathrm{S}=0.04 \mathrm{~m}^{2}\right)$, обшитую мельничным газом.

Основным методом учета Decapoda было визуальное наблюдение с берега и под водой в диапазоне глубин от уреза воды до 26 м, так как большинство видов десятиногих ракообразных относительно крупные и подвижные, плохо поддаются учету при дночерпательных сборах. Отлов фактического материала осуществляли также сачком, с помощью насоса и ловушек. Кроме этого в исследованиях был применен метод трансект (Методы ландшафтных ..., 2005). После идентификации и соответствующих измерений живых Decapoda без повреждений возвращали в естественную среду обитания.

\section{Результаты и обсуждение}

При проведении сравнительного анализа не выявлено существенных отличий в размере и массе рыб одного пола и возраста из разных бухт. Индекс печени и упитанность в большинстве случаев выше у рыб из бухт Стрелецкой и Балаклавской (табл. 1). Важно отметить, что повышение размерно-массовых величин с возрастом скорпены происходит слабо или вообще отсутствует (особенно у самцов), что свидетельствует о плохих условиях нагула в период с 2012-2013 гг. до настоящего времени. Однако ерши из бухты Севастопольской находятся в лучшем функциональном состоянии. Это выражалось в увеличении размера, массы и ИП рыб с возрастом. Ранее мы анализировали не только размер и массу скорпены, но и состояние желчного пузыря. Его цвет, прозрачность и форма у $78.1 \%$ рыб из этой акватории были оптимальными, а значения массы и размера особей высокими. С учетом этих данных можно предположить, что накормленность S. porcus из бухты Севастопольской лучше, чем в других бухтах (Хараева, 2018).

Ранее не было выявлено отличий по степени наполнения желудков у самок и самцов и не обнаружена разница в пищевых объектах скорпены разного возраста (Кузьминова, 2017), поэтому мы рассчитали процент рыб с разной степенью наполнения желудков в текущий период наблюдений без дифференциации массива по критериям пол и возраст. Отмечено, что как и в пре-

Популяционные параметры морского ерша в бухтах г. Севастополя в 2016-2018 гг.

Таблица 1

\begin{tabular}{|c|c|c|c|c|c|c|c|c|c|}
\hline \multirow{2}{*}{ Параметр } & \multirow{2}{*}{ Бухта } & \multicolumn{4}{|c|}{ Возраст самок } & \multicolumn{4}{|c|}{ Возраст самцов } \\
\hline & & 2 года & 3 года & 4 года & 5 лет & 2 года & 3 года & 4 года & 5 лет \\
\hline \multirow[t]{4}{*}{$\mathrm{SI}, \mathrm{CM}$} & Севастопольская & $11.0 \pm 0.4$ & $11.9 \pm 0.3$ & $11.9 \pm 0.3$ & $12.09 \pm 0.3$ & $10.6 \pm 0.4$ & $11.6 \pm 0.4$ & $11.9 \pm 0.6$ & $11.1 \pm 0.3$ \\
\hline & Карант инная & $11.6 \pm 0.5$ & $11.4 \pm 0.4$ & $10.9 \pm 0.3$ & $11.4 \pm 0.3$ & $10.8 \pm 0.5$ & $10.4 \pm 0.4$ & $10.7 \pm 0.4$ & $10.1 \pm 0.5$ \\
\hline & Стрелецкая & $10.0 \pm 0.9$ & $12.5 \pm 1.2$ & $11.5 \pm 0.7$ & $12.6 \pm 1.0$ & $9.9 \pm 0.6$ & $11.0 \pm 0.9$ & $9.7 \pm 0.6$ & $9.7 \pm 0.5$ \\
\hline & Балаклавская & - & $11.5 \pm 0.9$ & $11.6 \pm 0.6$ & $10.05 \pm 0.7$ & - & $10.9 \pm 0.2$ & $10.3 \pm 0.6$ & $13.1 \pm 1.0$ \\
\hline \multirow{4}{*}{$\begin{array}{l}\text { Мacca рыбы, } \\
\text { г }\end{array}$} & Севастопольская & $57.56 \pm 7.4$ & $70.6 \pm 5.0$ & $73.6 \pm 5.0$ & $75.1 \pm 4.9$ & $53.5 \pm 4.3$ & $67.4 \pm 7.3$ & $74.2 \pm 10.4$ & $55.3 \pm 4.5$ \\
\hline & Карантинная & $75.4 \pm 14.8$ & $67.6 \pm 8.4$ & $54.7 \pm 5.8$ & $68.7 \pm 5.4$ & $50.4 \pm 7.2$ & $50.4 \pm 5.6$ & $52.2 \pm 5.8$ & $46.6 \pm 5.9$ \\
\hline & Стрелецкая & $57.38 \pm 19.0$ & $111.62 \pm 30.9$ & $73.19 \pm 11.8$ & $106.5 \pm 26.4$ & $41.4 \pm 8.3$ & $71.9 \pm 19.5$ & $44.8 \pm 8.8$ & $44.9 \pm 8.1$ \\
\hline & Балаклавская & - & $73.9 \pm 14.3$ & $76.1 \pm 10.1$ & $51.4 \pm 14.2$ & - & $63.3 \pm 20.1$ & $55.3 \pm 10.8$ & $110.2 \pm 22.4$ \\
\hline \multirow[t]{4}{*}{ ИП, \%о } & Севастопольская & $16.7 \pm 2.4$ & $20.08 \pm 1.8$ & $21.4 \pm 1.7$ & $30.3 \pm 6.9$ & $26.0 \pm 4.3$ & $25.1 \pm 4.8$ & $21.8 \pm 2.4$ & $22.6 \pm 3.5$ \\
\hline & Карантинная & $24.4 \pm 5.1$ & $29.1 \pm 3.1$ & $29.7 \pm 4.7$ & $31.5 \pm 3.4$ & $20.4 \pm 2.0$ & $31.9 \pm 4.5$ & $27.5 \pm 5.5$ & $28.9 \pm 4.8$ \\
\hline & Стрелецкая & $27.61 \pm 6.2$ & $43.32 \pm 5.39$ & $23.51 \pm 3.43$ & $33.29 \pm 7.0$ & $38.5 \pm 14.1$ & $35.7 \pm 7.7$ & $19.2 \pm 3.1$ & $20.8 \pm 3.1$ \\
\hline & Балаклавская & - & $37.35 \pm 6.7$ & $32.5 \pm 5.5$ & $28.7 \pm 10.2$ & - & $23.5 \pm 6.1$ & $27.8 \pm 8.4$ & $40.9 \pm 8.1$ \\
\hline \multirow{4}{*}{$\begin{array}{l}\text { Упитанность, } \\
\%\end{array}$} & Севастопольская & $3.7 \pm 0.2$ & $3.5 \pm 0.05$ & $3.5 \pm 0.06$ & $3.5 \pm 0.1$ & $3.8 \pm 0.2$ & $3.5 \pm 0.2$ & $3.6 \pm 0.1$ & $3.2 \pm 0.2$ \\
\hline & Карантинная & $3.7 \pm 0.09$ & $3.6 \pm 0.07$ & $3.4 \pm 0.07$ & $3.7 \pm 0.1$ & $3.3 \pm 0.07$ & $3.7 \pm 0.1$ & $3.6 \pm 0.1$ & $3.7 \pm 0.1$ \\
\hline & Стрелецкая & $4.14 \pm 0.23$ & $3.83 \pm 0.14$ & $3.54 \pm 0.09$ & $3.94 \pm 0.23$ & $3.4 \pm 0.1$ & $3.7 \pm 0.1$ & $3.7 \pm 0.09$ & $3.6 \pm 0.06$ \\
\hline & Балаклавская & - & $3.4 \pm 0.1$ & $3.5 \pm 0.1$ & $3.9 \pm 0.3$ & - & $3.6 \pm 0.09$ & $3.8 \pm 0.08$ & $3.3 \pm 0.1$ \\
\hline
\end{tabular}

Примечание: SI - стандартная длина, ИП - индекс печени. 
дыдущие годы (2011-2014 гг.), больше всего ершей отловлено с пустыми желудками (56.1 \%), на втором месте - число скорпен с максимально наполненными желудками (21.93). Это связано с длительными перерывами между приемами пищи и ночным временем охоты (Кузьминова, 2017). Ерши с 1, 2, 3 и 4 степенями наполнения желудков были встречены в количестве 13.01, 1.48, 2.65 и $4.83 \%$ соответственно.

В годовом спектре питания ерша различают два типа смены пищевых объектов: а) закономерная сезонная смена, связанная с параллельной сезонной ритмичностью пищеварительного тракта; б) вынужденная смена, происходящая под влиянием миграции пищевых организмов (Фортунатова, 1949).

Рассмотрим оба типа смен пищевого рациона ерша, представленных в работах середины XX в. в сравнении с нашими данными. Ранее было установлено, что процент веса и частоты встречаемости гидробионтов в пищевом рационе взрослых особей $S$. porcus в разные сезоны отличался (Фортунатова, 1949). Зимой преобладали представители Decapoda (56 \% по весу и $39 \%$ по частоте встречаемости), весной - Pisces по весу (52\%) и Decapoda по частоте встречаемости (39\%), летом Decapoda (54\% по весу и $47 \%$ по частоте встречаемости). Осенью повторялась та же картина, что и весной - Pisces преобладали по весу (53\%), Decapoda - по частоте встречаемости (42\%). Следовательно, всего за год в питании ерша значительную роль играли представители Malacostraca (54\% по весу и 69 \% по частоте встречаемос-
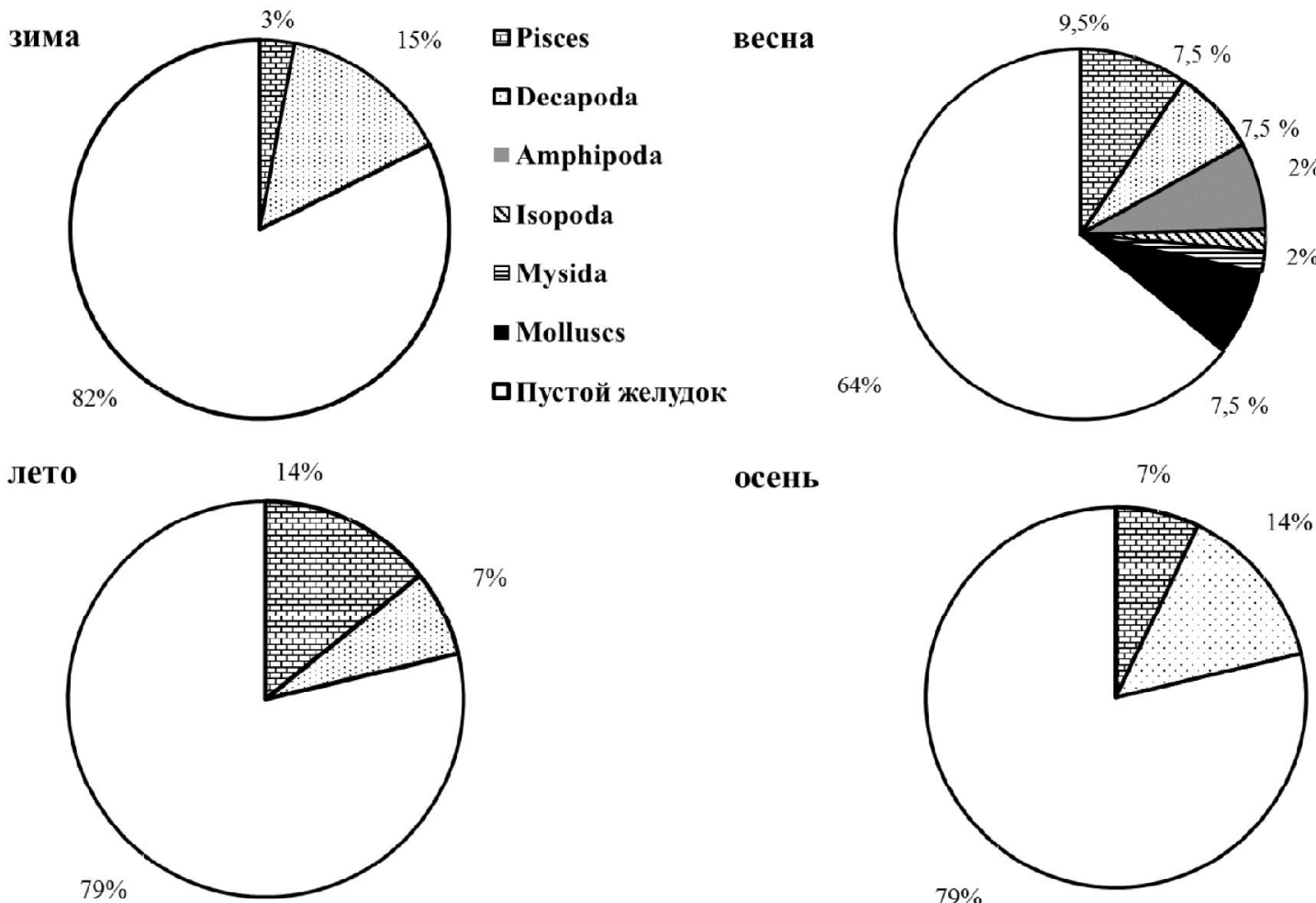

Рис. 1. Сезонная динамика питания S. porcus в современный период на примере особей, обитающих в бухте Севастопольской. 
ния в два раза больше, чем в светлый период. Высокий процент потребления ершами массовых видов Malacostraca скорее всего связан с тем, что кроме общего естественного места обитания у них также совпадают суточные ритмы жизнедеятельности (табл. 2).

S. porcus является ночным хищником. Большинство видов Malacostraca, представители которых отмечены нами в пищевом рационе ерша, также ведут ночной образ жизни, поднимаясь в темное время суток к поверхности. В литературе есть сведения о том, что подъем особей некоторых видов к поверхности и соответствующее увеличение их численности в ночное время могут быть связаны с повышением содержания углекислого газа и снижением концентрации кислорода в гуще макрофитов в темное время суток (Ledoyer, 1961; Маккавеева, 1979).

Виды рыб, обнаруженные в желудках скорпены (табл. 3), ведут активный образ жизни в дневное время суток (Световидов, 1964), тогда как ночью скорость их передвижения снижается и они становятся легкой добычей для малоподвижного ерша.

Следует отметить, что в 2017-2018 гг. по сравнению с данными прошлого века и начала нынешнего столетия (до 2014 г. включительно) изменилось пищевое разнообразие объектов питания S. porcus из исследуемых акваторий. В середине прошлого века в пищевом рационе ершей, обитающих в прибрежной зоне от бухты Ласпи до акватории г. Ялты, преобладали ставрида и султанка, из Decapoda - Portunus. В желудках $S$. porcus из акваторий Севастополя также отмечена ставрида и представители родов Decapoda: Xantho, Upogebia, Leander (syn. Palaemon) и Crangon; при этом высокий процент встречаемости приходился на рака-крота Upogebia, a низкий на креветок. Кроме этого, в желудках скорпен были найдены представители других высших ракообразных - Amphipoda, Isopoda и Mysida, a также в небольшом количестве - моллюски и полихеты. В Севастопольской бухте ерши питались в основном рыбой Trachurus mediterranus и крабами Xantho (Фортунатова, 1949). Помимо перечисленных объектов питания, в желудках S.porcus найдены Atherina mochon pontica, Crenilabrus griseus, Cr. ocelatus, Blennius, Gobiidae, Carcinidae, Eriphia verrucosa, Pachygrapsus marmoratus, Carcinus aestuarii, Liocarcinus vernalis, Liocarcinus navigator, Diogenes pugilator, Pisidia longimana и Pilumnus hirtellus (Виноградов, 1949; Хирина, 1950; Световидов, 1964; Снигирев, 2011; Кузьминова, 2017).

В среднем за период 2017-2018 гг. в желудках $16 \%$ особей всех исследованных нами скорпен из бухты Севастопольской найдены высшие ракообразные (из них $10 \%$ - Decapoda, $3.5 \%$ Amphipoda, $1.5 \%$ - Isopoda и $1 \%$ - Mysida), $8 \%$ - Pisces, $3.5 \%$ - Mollusca (рис. 2). У ершей, пойманных в бухте Карантинной, из Malacostraса в желудках отмечены только Amphipoda (8 \% от общего числа исследованных рыб), у 5 \% найдены Mollusca, у 2.5 \% - Annelida. В бухте Стрелецкой в пищевом рационе скорпены преобладают Pisces (32\%), а из Malacostraca обнаружены только Decapoda (11\%). Сходная картина наблюдается и в бухте Балаклавской: 39.5 \% приходится на Pisces и $14 \%$ - на Decapoda. Желедцки остальных препарированных рыб, пойманных в этих бухтах, были пустыми или в них присутствовали остатки слизи.

Таксономический состав высших ракообразных и рыб, обитающих в бухтах Севастопольской, Карантинной, Стрелецкой и Балаклавской, представлен в табл. 3. В пищевом рационе скорпен из бухт Севастопольской и Карантинной по видовому разнообразию преобладают представители отряда Amphipoda, в то время как у ершей из бухт Стрелецкой и Балаклавской найдены только Decapoda. Качественный состав пищевых объектов скорпены из бухты Севастопольской шире по сравнению с другими исследованными акваториями. В то время как в Севастопольской бухте основная доля рациона приходилась на рыб, декапод и амфипод, в Стрелецкой и Балаклавской бухтах - исключительно на рыб.

В современный период в желудках ерша не обнаружены такие представители Decapoda, как E. verrucosa, P. marmoratus, L. vernalis, L. navigator и C. crangon, обитающие в исследованных бухтах и ранее отмеченные в пищевом рационе скорпены (Виноградов, 1949; Фортунатова, 1949). Из постоянно встречающихся в исследуемых бухтах видов следует отметить $X$. poressa, D. pugilator, P. longimana, U. pusilla, P. hirtellus, P. elegans и $P$. adspersus. В пищевом комке ерша нами обнаружен лишь один вид портунид - C. aestuarii. Некоторые из перечисленных видов высших ракообразных (молодь декапод, мелкие кумовые и амфиподы) являются пищей для рыб Mullus barbatus ponticus, P. elegans и мизиды - для T. mediterraneus (Световидов, 1964), которые, в свою очередь, являются объектами питания скорпены (Виноградов, 1949; Фортунатова, 1949).

За исследованный период в желудках скорпены нами были обнаружены семь видов рыб: ставрида средиземноморская - T. mediterraneus (у 24 ершей), султанка - M. barbatus ponticus (у 15 экз.), атерина - Atherina sp. (у пяти особей), песчанка - Gymnammodytes cicerellus и хамса - Engraulis encrasicolus (у 4 экз.), бычок-кругляк Neogobius melanostomus, сарган - Belone belone euxini. Ранее мы отмечали, что ставрида и султанка попадались в желудках S. porcus во всех изученных акваториях (Кузьминова, 2017), песчанка, атерина, хамса и единично малек саргана - только у ершей из бухты Стрелецкой, один бычок-кругляк - в желудке скорпены из бухты Севастопольской. По сравнению с периодом 2011- 


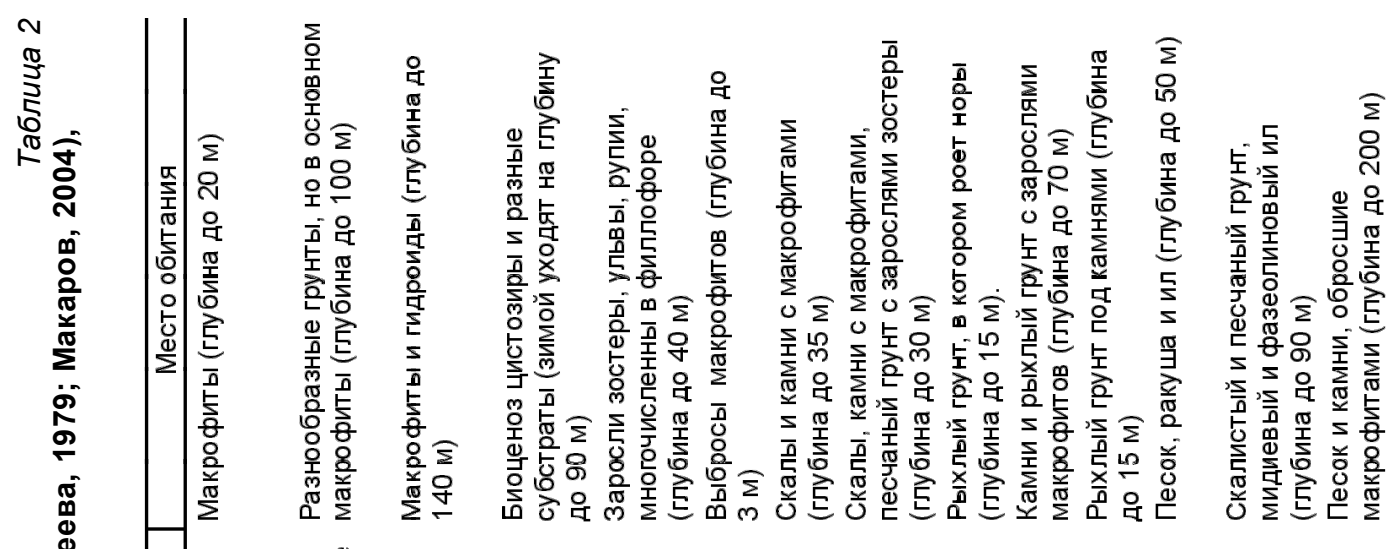



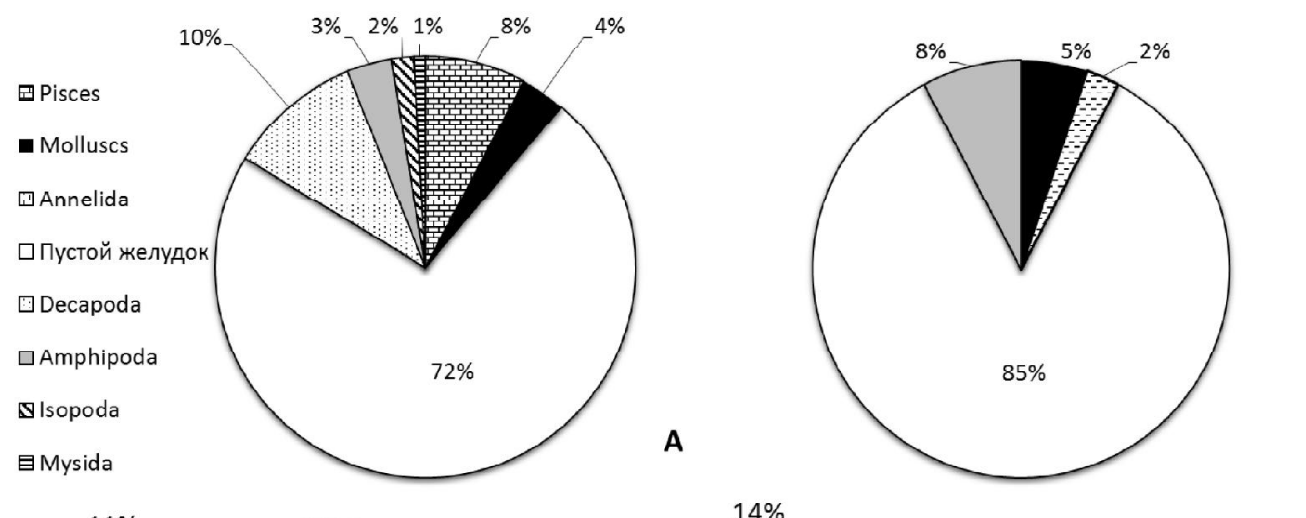

Б

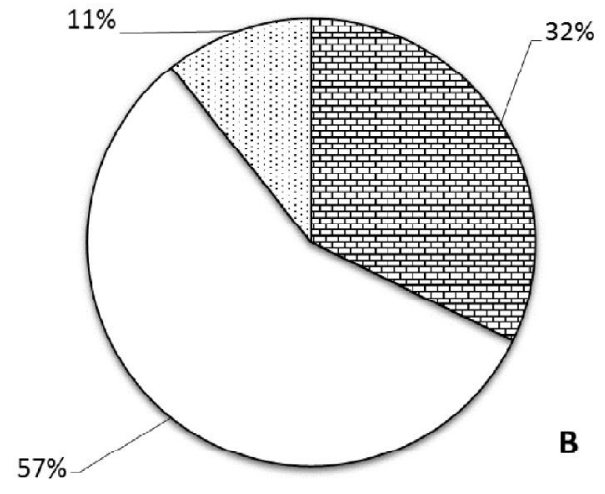

A

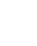

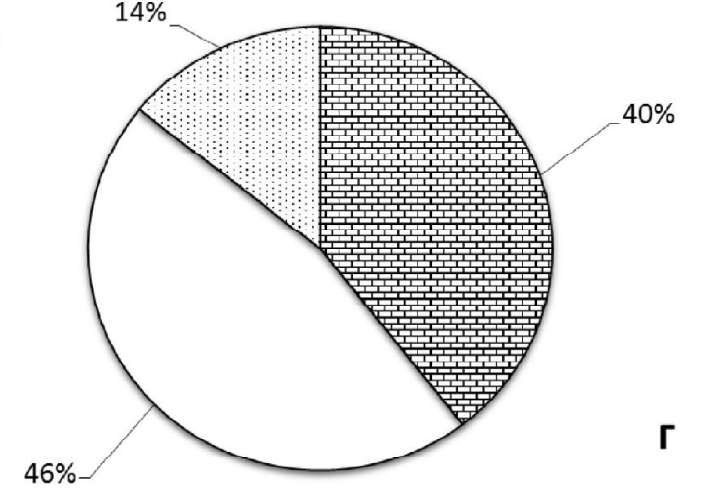

Рис. 2. Питание Scorpaena porcus, обитающих в бухтах Севастопольской (А), Карантинной (Б), Стрелецкой (В), Балаклавской (Г) в современный период.

2014 гг. мы чаще находили в желудках ершей атерину и песчанку, но ни разу не фиксировали спикару. Ставрида встречалась только в желудках особей старше трех лет, а барабуля - у скорпен всех возрастов. Кроме того, отмечены единичные экземпляры представителей родов Symphodus и Parablennius, а также такие виды рыб, как Uranoscopus scaber, Spicara flexuosa, Hippocampus hippocampus, Merlangius merlangus euxinus.

Помимо рыб и высших ракообразных, в пищевом комке ерша в незначительном количестве отмечены представители Annelida и Mollusca. Изредка попадаются остатки макрофитов.

Как следует из полученных данных, S. porcus из бухт Балаклавской и Стрелецкой питается в основном рыбой и десятиногими ракообразными (табл. 3), что, вероятно, сказывается на упитанности и значении индекса печени ерша (табл. 1). Высокие значения данных показателей могут быть связаны с калорийностью пищевого рациона скорпены в этих бухтах. Так, средняя калорийность годовиков T. mediterraneus и M. barbatus ponticus составляет 28410 и 11710 Мкал соответственно (Шульман, 1972), в то время как энергетический эквивалент веса большинства Malacostraca относительно низкий: D. spinosa - 4.029.

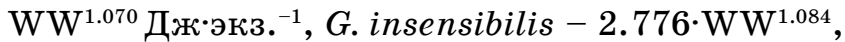
P. adspersus $-3.475 \cdot \mathrm{WW}$, P. elegans $-23,824 \cdot \mathrm{DW}$ Дж. экз. ${ }^{-1}$, где WW - сырой вес мг•экз. ${ }^{-1}, \mathrm{DW}-$ сухой вес мг•экз. ${ }^{-1}$ (Александров, 2001).
В нашем случае следует говорить скорее о вынужденной смене пищевых объектов $S$. porcus, происходящей под влиянием их миграции или исчезновения из мест естественного обитания. Возможно, такое изменение пищевого рациона $S$. porcus связано как с уже ранее упоминавшейся тенденцией восстановления прибрежной ихтиофауны (Вдодович, 2008; Климова, 2010; Экотоксикологические ..., 2016), так и с увеличением биомассы зообентоса (Ревков, 2011), что может быть обусловлено изменением экологических условий среды обитания организмов. С другой стороны, переход ерша на питание с Decapoda на более мелкие виды Malacostraca в 50 \% исследованных бухт, вероятно, связан с резким сокращением численности десятиногих ракообразных по сравнению с прошлым веком. За последние десятилетия значительно сократилась численность таких видов Malacostraca, как G. insensibilis, B. sexdentatus, L. seticaudata, L. navigator и M. czernjawskii, ранее широко распространенных в севастопольских бухтах (Тимофеев, 2016). Изменения, произошедшие в биоценозах исследуемых бухт за последние десятилетия, естественным образом оказывают влияние на трофическую структуру (табл. 4) и таксономический состав обитающих там Malacostraca. Следует отметить смену лидеров в трофической структуре гидробионтов бухт Севастопольской, Карантинной и Балаклавской. В бухте Севастопольской на смену таким представителям Decapoda, как Diogenes, Portunus, Athanas, Xantho и Macropodia пришли 
Таблица 3

Видовой состав пищевых объектов скорпены в период 2005-2018 гг. (по данным содержимого в желудках и/или в среде)

\begin{tabular}{c|c|c|c|c}
\hline \multirow{2}{*}{ Вид } & \multicolumn{3}{|c}{ Район (бухта) } \\
\cline { 2 - 4 } & $\begin{array}{c}\text { Севасто- } \\
\text { польская }\end{array}$ & $\begin{array}{c}\text { Кантин } \\
\text { ная }\end{array}$ & $\begin{array}{c}\text { Стрелец- } \\
\text { кая }\end{array}$ & $\begin{array}{c}\text { Балак- } \\
\text { лавская }\end{array}$ \\
\hline
\end{tabular}

Trachurus mediterraneus (Steindachner, 1868)

Mullus barbatus ponticus Essipov, 1927

Spicara flexuosa Rafinesque, 1810

Atherina $\mathrm{sp}$.

Gymnammodytes cicerelus (Rafinesque, 1810)

Engraulis encrasicolus (Linnaeus, 1758)

Belone belone euxini Gunther, 1866

Neogobius melanostomus (Pallas, 1814)

Merlangius merlangus euxinus (Nordmann, 1840)

Hippocampus hippocampus (Linnaeus, 1758)

Uranoscopus scaber Linnaeus, 1758

Symphodus sp.

Parablennius sp.

Athanas nitescens Leach, 1814 Lysmata seticaudata (Risso, 1816) Hippolyte leptocerus (Heller, 1863) Palaemon adspersus Rathke, 1837 Palaemon elegans Rathke, 1837 Palaemon serratus (Pennant, 1777) Upogebia pusilla (Petagna, 1792) Diogenes pugilator Roux, 1828 Clibanarius erythropus Latreille, 1818 Pisidia longimana (Risso, 1816) Eriphia verrucosa Forskal, 1775

Pachygrapsus marmoratus (Fabricius, 1793)

Macropodia czernjawskii (Brandt, 1880)

Pilumnus hirtellus (Linnaeus, 1761)

Liocarcinus vernalis (Risso, 1816)

Carcinus aestuarii Nardo, 1847

Xantho poressa (Olivi, 1792)

Brachynotus sexdentatus Risso, 1827

Decapoda gen. et sp. indet.

Palaemon sp.

Ampithoe hellery G. Karaman, 1975 Ampithoe ramondi Audouin, 1826

Apherusa bispinosa (Bate, 1857)

Caprella acanthifera (Czernjavski, 1868)

Caprella liparotensis Haller, 1879

Dexamine spinosa (Montagu, 1813)

Echinogammarus olivii M.-Edw ards, 1830

Erichthonius difformis M.- Edw ards, 1830

Gammarus insensibilis Stock, 1966

Gammarelus carinatus

Gammarellus angulosus (Rathke, 1843)

Hyale schmidtii (Heller, 1866)

Hyale perieri (Lucas, 1846)

Hyale pontica Rathke, 1837

Jassa ocia (Bate, 1862)

Microdeutopus gryllotalpa A.Costa

Microprotopus minutus Sovinsky, 1893

Monocorophium insidiosum (Craw ford, 1937)

Naesa bidentata (Adams, 1800)

Nototropis guttatus Costa, 1853
Gammaridae, Cumacea и Upogebia pussila, в бухте Карантинной массовый вид Diogenes pugilator уступил свои позиции Gammaridae (Зернов, 1913; Миловидова, 1975; Маккавеева, 1979; Грезе, 1985; Многолетние ..., 1992; Миронов, 2003; Санитарно-биологические ..., 2018). В бухте Балаклавской отмечено преобладание видов Nototropis guttatus, Diogenes pugilator, в то время как в середине прошлого века здесь в основном доминировал вид Upogebia litoralis (совр. Upogebia pusilla) (Арнольди, 1941; Миронов, 2003; Санитарно-биологические ..., 2018). В бухте Стрелецкой к лидирующим видам сестонофагам Malacostraca добавились такие виды детрито-, фито- и детритофитофаги, как Stenothoe monoculoides, Pleonexes gammaroides, Dynamene bicolor, Dexamine spinosa, Ampithoe vaillanti, Hyale pontica, Biancolina algicola, Apherusa bispinosa, Erichthonius difformis (Зернов, 1913; Миловидова, 1975; Маккавеева, 1979; Грезе, 1985; Миронов, 2003; Санитарно-биологические ..., 2018).

Известно, что разные организмы имеют неодинаковую норму реакции на смену условий среды их обитания. Например, такой вид, как Apherusa bispinosa, найденный в желудках скорпен, обитающих в бухте Севастопольской, в 2002 г. обнаружен в акватории юго-восточного Крыма на глубинах 3-9 м на загрязненных участках. Отмечено увеличение численности этой амфиподы в зоне интенсивного загрязнения (Гринцов, 2004). При этом танаидовый рак Chondrochelia savignyi, достигающий очень высокой численности в незагрязненных бухтах (Маккавеева, 1992) и являющийся пищевым объектом скорпены, в желудках рыб из исследуемых акваторий обнаружен не был.

Детальный обзор долговременных изменений видового состава рыб из Севастопольской и Карантинной бухт как основных районов отлова прибрежных видов представлен в работе Л.С. Овен с соавторами (2008). Начиная с 1913 г., в научной литературе появлялись сведения о видовом разнообразии 
ихтиофауны (насчитывали 40 видов), об уловах высокоценных промысловых видов, характере нереста разных видов и пр. Из-за строительства мола в начале 80-х гг. прошлого века нарушился водообмен и к 1990 г. промысел в этих акваториях прекратился. В бухтах в этот период насчитывалось от девяти до 27 видов рыб. Постепенно даже после таких существенных изменений в экосистеме, число видов стало восстанавливаться, и уже к 2003-2007 гг. их насчитывали 49. Авторы указывают и на тот факт, что если в 1990-х гг. численность рыб в бухтах (особенно в Севастопольской) была минимальной и в донные ловушки ИнБЮМ попадали единичные экземпляры, а годовой улов составлял $3-4$ кг, то в начале XXI в. такое количество рыбы отлавливали уже за сутки (особенно в весенне-летний период). По нашим наблюдениям и данным литературы (Экотоксикологические ..., 2016), с 2008 по 2014 г. разнообразие ихтиофауны в прибрежной зоне Сeвастополя составляло 49 видов. Число донных рыб все еще низкое в Севастопольской бухте (5-7 видов); в бухте Карантинной их доля выше (11-12 видов в разные годы).

Повышенная рекреация, интенсивное загрязнение вод и разрушение местообитаний морских организмов вследствие отрицательных антропогенных факторов, изменение площади произрастания макрофитов, являющихся естественной средой обитания для большинства видов Malacostraca и некоторых Pisces, закономерно отражаются на состоянии их популяций, уменьшение численности которых, в свою очередь, способствует смене пищевого рациона консументов более высоких порядков, к которым относится и $S$. porcus.

\section{Выводы}

Существенных отличий в размере и массе рыб одного пола и возраста из разных бухт не выявлено. Индекс печени и упитанность в большинстве случаев выше у рыб из бухт Стрелецкой и Балаклавской, что может быть связано с калорийностью пищевого рациона скорпены. Повышение размерно-массовых величин с возрастом у скорпены происходит слабо или вообще отсутствует (особенно у самцов), что свидетельствует о плохих условиях нагула в период с 2012-2013 гг. до настоящего времени. S. porcus из бухты Севастопольской находятся в лучшем функциональном состоянии. Это выражалось в увеличении размера, массы и ИП рыб с возрастом.
Окончание табл. 3

Район (бухта)

\begin{tabular}{l|c|c|c|c}
\hline \multirow{2}{*}{ Вид } & \multicolumn{4}{|c}{ Район (бухта) } \\
\cline { 2 - 5 } & $\begin{array}{c}\text { Севасто- } \\
\text { польская }\end{array}$ & $\begin{array}{c}\text { Карантин- Стрелец- } \\
\text { ная }\end{array}$ & $\begin{array}{c}\text { Балак- } \\
\text { кая }\end{array}$ & лавская \\
\hline
\end{tabular}

\begin{tabular}{lllll}
\hline & - & + & -
\end{tabular}

$+\quad-\quad-\quad-1$

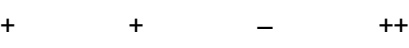

$\begin{array}{llll}- & X & - & - \\ X & X & - & -\end{array}$

\section{Is opoda}

$+\quad-\quad+$

$+\quad+\quad-\quad+$

X $+\quad+\quad++$

$+\quad-\quad-$

Mysida

$+-$

$\begin{array}{cccc}- & + & - & ++ \\ X & - & - & -\end{array}$

$\begin{array}{ccccc}- & + & & & \\ + & + & +\end{array}$

Cumella limicola Sars, 1879

Iphinoe elisae Bacescu, 1950

Tanais dulongii (Audouin, 1826)

$+\begin{array}{lll}+ & - & ++ \\ + & - & ++\end{array}$

$+$

Tanaidacea

$+\quad++$

(1)

$\begin{array}{llll}+ & + & + & - \\ + & + & - & +\end{array}$

$+$

Примечание: X - виды, найденые в желудках S. porcus (собственные данные); ++ - данные, любезно предоставленные вед.н.с. ФИЦ ИнБЮМ к.б.н. Н.К. Ревковым; (*) - по (Болтачев, Карпова, 2012).

Анализ сезонной динамики питания скорпены в современный период на примере особей, обитающих в бухте Севастопольской, показал, что зимой, весной и осенью в пищевом комке $S$. porcus преобладают Malacostraca. Летом наибольшая частота встречаемости отмечена у Pisces, поскольку именно летом (и в некоторые годы осенью) численность султанки и ставриды в прибрежной зоне г. Севастополя достигает максимума и их доля в акватории в 2018 г. составила 48 и $14 \%$ соответственно.

Отмечено изменение пищевого рациона $S$. porcus, что, по-видимому, связано как с тенденцией восстановления прибрежной ихтиофауны, так и с увеличением биомассы зообентоса, обусловленным изменением экологических условий среды обитания организмов. Переход ерша на питание более мелкими видами Malacostraca в 50 \% исследованных бухт, вероятно, произошел из-за резкого сокращения численности десятиногих ракообразных по сравнению с прошлыми годами исследований. В современный период в желудках ерша не обнаружены такие представители Decapoda, как E. verrucosa, P. marmoratus, L. vernalis, L. navigator и C. crangon, обитающие в исследованных бухтах и ранее отмеченные в пищевом рационе скорпены. Из постоянно встречающихся в исследуемых бухтах видов следует отметить $X$. poressa, D. pugilator, $P$. longimana, $U$. pusilla, P. hirtellus, P. elegans и P. adspersus. В пищевом комке ерша нами обнаружен лишь один вид портунид - C. aestuarii. 


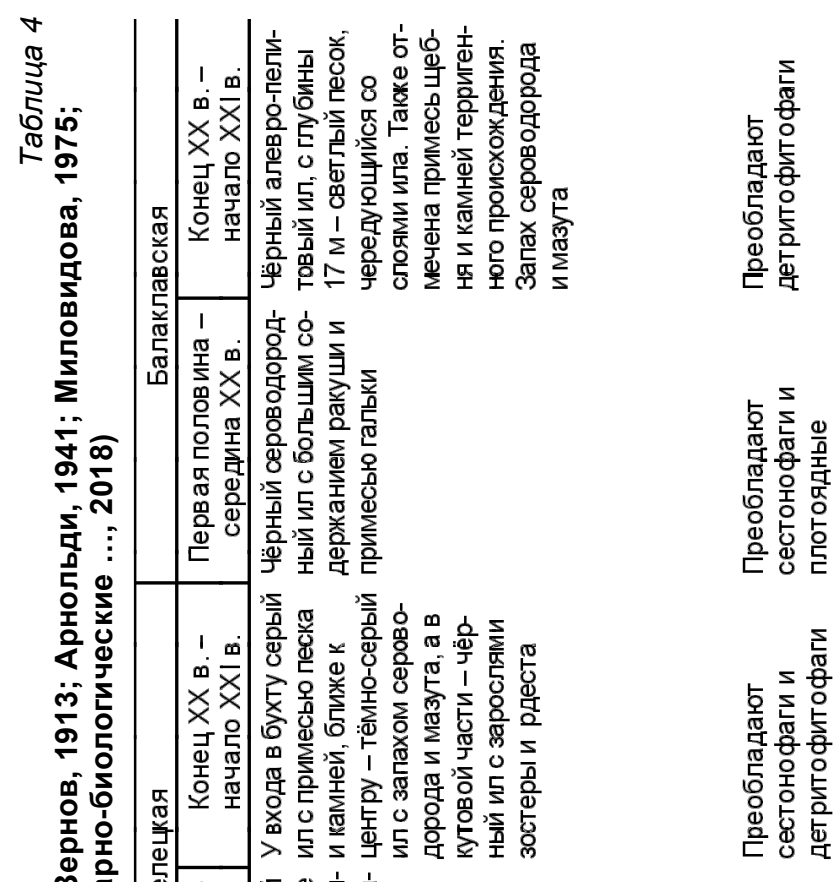

Авторы выражают большую признательность сотрудникам ФИЦ ИнБЮМ д.б.н. С.В. Алемову, а также к.б.н. Н.К. Ревкову за ценные указания и консультации, предоставление материала для подготовки статьи.

Работа выполнена в рамках тем «Молисмологические и биогеохимические основы гомеостаза морских экосистем» (Государственное задание № 0828-20190006) и «Мониторинг биологического разнообразия гидробионтов Черноморско-Азовского бассейна и разработка эффективных мер по его сохранению» (№ 10012014-0014).

\section{ЛИТЕРАТУРА}

Александров, Б. Г. Калорийность беспозвоночных Черного моря. II Макрозообентос / Б. Г. Александров // Экология моря. - 2001. - Вып. 56. - С. 71-76.

Арнольди, Л. В. Материалы по количественному изучению зообентоса в Черном море / Л. В. Арнольди // Труды Зоологического института АН СССР. 1941. - Т. 7, вып. 2. - С. 94-113.

Болтачев, А. Р. Ихтиофауна прибрежной зоны Ceвастополя (Черное море) / А. Р. Болтачев, Е. П. Карпова // Морской экологический журнал. - 2012. T. 11, № 2. - С. 10-27.

Болтачев, А. Р. Фаунистическая ревизия чужеродных видов рыб в Черном море / А. Р. Болтачев, Е. П. Карпова // Российский журнал биологических инвазий. - 2014. - № 3. - С. 2-26.

Васильева, Е. Д. Рыбы Чёрного моря. Определитель морских, солоноватоводных, эвригалинных и проходных видов с цветными иллюстрациями, собранными С. В. Богородским / Е. Д. Васильева. - Москва : Изд-во ВНИРО, 2007. - 238 с.

Вдодович, И. В. Питание личинок черноморских бычков в прибрежной акватории Севастополя в летний период по материалам 2003-2009 гг. / И. В. Вдодович // Экология моря. - 2008. - Вып. 76. - С. 4044.

Виноградов, К. А. О возможности акклиматизации в Черном море новых объектов промысла / К. А. Виноградов // Зоологический журнал. - 1949. - Т. 28, вып. 2. - С. 14-17.

Грезе, И. И. Высшие ракообразные. Бокоплавы : Фауна Украины : в 40 т. / И. И. Грезе. - Киев : Наукова думка. - 1985. - Т. 26, вып. 5. - 172 с.

Гринцов, В. Г. Отряд Амфиподы или Разноногие раки (бокоплавы) / В. Г. Гринцов // Карадаг. Гидробиологические исследования : Сборник научных трудов, посвященный 90-летию Карадагской научной станции им. Т. И. Вяземского и 25-летию Карадагского природного заповедника НАН Украины : Кн. 2. - Симферополь : СОНАТ. - 2004. - С. 391-397.

Закутский, В. П. Бентогипонейстон Черного и Азовского морей. Экологическая биогеография контактных зон моря / В. П. Закутский. - Киев : Наукова думка, 1968. - C. 71-90.

Зернов, С. А. Къ вопросу объ изученіи жизни Чернаго моря / С. А. Зернов // Записки императорской академии наукъ. - 1913. - Т. 32. - 299 с.

Зообентос в биотопе палеорусла реки Черная на шельфе прибрежной зоны юго-западного Крыма / М. Б. Гулин, Л. В. Бондаренко, М. В. Коваленко, В. А. Тимофеев // Экология моря. - 2009. - Вып. 78. - С. 4449.

Климова, Т. Н. Ихтиопланктон прибрежной акватории юго-западного Крыма в 2002-2008 гг. / Т. Н. 
Климова // Морський екологічний журнал. - 2010. Т. 9, № 1. - С. 39-52.

Кобякова, 3. И. Отряд десятиногие - Decapoda / 3. И. Кобякова, М. А. Долгопольская. - Киев : Наукова думка, 1969. - Т. 2. - С. 270-362.

Копий, В. Г. Макрозообентос биотопов зоны псевдолиторали бухты Казачья (Черное море, Крым) / В. Г. Копий, Л. В. Бондаренко, И. Н. Аннинская // Бюллетень МОИП. - 2007. - Т. 122, вып. 2. - С. 34-42.

Кузьминова, Н. С. Современные сведения о питании и пищеварении черноморской скорпены (Scorpaena porcus L.) / Н. С. Кузьминова, И. И. Чеснокова, С. В. Архипова // Экосистемы. - 2017. - Вып. 10. - С. 5263.

Макаров, Ю. Н. Десятиногие ракообразные. Фауна Украины / М. В. Макаров. - Киев : Наукова думка, 2004. - Т. 26, вып. 1, 2. - 430 с.

Маккавеева, Е. Б. Беспозвоночные зарослей макрофитов Черного моря / Е. Б. Маккавеева - Киев : Наукова думка, 1979. - 229 с.

Маккавеева, Е. Б. Экология клешненосных осликов (Anisopoda) и равноногих раков (Isopoda) в Черном море / Е. Б. Маккавеева // Вестник зоологии. 1992. - № 5. - С. 46-50.

Макрозообентос рыхлых грунтов под мидийно-устричной фермой района марихозяйства (Черное море, район Севастополя) / Н. А. Болтачева, М. В. Макаров, Л. В. Бондаренко, М. А. Ковалёва // Морской биологический журнал. - 2018. - Т. 3, № 1. - С. 9-22. doi: $10.21072 / \mathrm{mbj} .2018 .03 .1 .02$

Методы исследовательского дела в рыбоводстве // Методические указания к практическим занятиям по теме «Изучение питания и пищевых взаимоотношений рыб» для студентов III курса направления 6.090201 «Водные биоресурсы и аквакультура» / сост. В. В. Кракатица. - Керчь, 2010. - 28 с.

Методы ландшафтных исследований и оценки запасов донных беспозвоночных и водорослей морской прибрежной зоны / Е. И. Блинова, О. Ю. Вилкова, Д. М. Милютин, О. А. Пронина, В. А. Штрик // Изучение экосистем рыбохозяйственных водоемов, сбор и обработка данных о водных биологических ресурсах, техника и технология их добычи и переработки. 2005. - Вып. 3. - 134 с.

Миловидова, Н. Ю. Изменение донных биоценозов севастопольских бухт за период с 1913 по 1973 г. / Н. Ю. Миловидова // Биология моря. - 1975. - Вып. 35. - С. 117-124.

Миронов, О. Г. Санитарно-биологические аспекты экологии севастопольских бухт в XX веке / О. Г. Миронов, Л. В. Кирюхина, С. В. Алёмов. - Севастополь : ЭКОСИ-Гидрофизика, 2003. - 185 с.

Многолетние изменения зообентоса Черного моря / В. Е. Заика, М. И. Киселева, Т. В. Михайлова, Е. Б. Маккавеева, Н. Г. Сергеева, А. С. Повчун, Е. А. Колесникова, В. Д. Чухчин. - Киев : Наукова думка. 1992. -248 с.

Овен, Л. С. Многолетняя динамика видового состава и численности рыб Черного моря в районе Севастополя / Л. С. Овен, Л. П. Салехова, Н. С. Кузьминова // Риб. госп-во України. - 2008. - № 4 (57). - С. 15-18.

Правдин, И. Ф. Руководство по изучению рыб / И. Ф. Правдин. - Москва : Пищевая промышленность, 1966. - $376 \mathrm{c}$.

Ревков, Н. К. Таксономический состав донной фауны Крымского побережья Черного моря / Н. К. Рев- ков // Современное состояние биоразнообразия прибрежных вод Крыма (черноморский сектор). - Севастополь : ЭКОСИ-Гидрофизика, 2003. - С. 209-218, $326-238$.

Ревков, Н. К. Макрозообентос украинского шельфа Черного моря / / Промысловые биоресурсы Черного и Азовского морей / Н. К. Ревков ; ред. В. Н. Еремеев, А. В. Гаевская, Г. Е. Шульман, Ю. А. Загородняя // НАН Украины, Институт биологии южных морей НАН Украины. - Севастополь : ЭКОСИ-Гидрофизика, 2011. - С. 140-162.

Ревков, Н. К. Структура таксоцена Malacostraca акватории бухты Круглой (юго-западный Крым, Черное море) / Н. К. Ревков, Л. В. Бондаренко, В. А. Гринцов // Экология моря. - 2008. - Вып. 77. - С. 38-43.

Санитарно-биологические исследования прибрежных акваторий юго-западного Крыма в начале XXI века / под ред. О. Г. Миронова, С. В. Алемова ; Институт морских биологических исследований им. А. О. Ковалевского РАН. - Симферополь : АРЕАЛ, 2018. $276 \mathrm{c.}$

Световидов, А. Н. Рыбы Черного моря / А. Н. Световидов. - Москва : Наука, 1964. - 553 с.

Снигирев, С. М. Питание и трофические связи трех массовых видов донных рыб в прибрежной акватории о. Змеиный в 2003-2007 гг. / С. М. Снигирев // Гидробиологический журнал. - 2011. - Т. 47, № 4. - С. 5265.

Тимофеев, В. А. Современное состояние видового разнообразия Decapoda (Crustacea) в бухтах г. Севастополя / В. А. Тимофеев, С. Е. Аносов // Морские биологические исследования: достижения и перспективы : Всероссийская научно-практическая конференция (19-24 сентября 2016, г. Севастополь). Т. 2. - Севастополь, 2016. - С. 174-178.

Фортунатова, К. Р. Биология питания морского ерша / К. Р. Фортунатова // Труды Севастопольской биологической станции. - 1949. - Т. 7. - С. 193-236.

Хараева, В. Б. Качественная оценка состояния желчного пузыря у черноморских рыб // Сборник тезисов докладов участников V Международной конференции научно-практических и исследовательских работ обучающихся «Лестница наук» (в авторской редакции) / В. Б. Хараева. - Владимир : Аркаим, 2018. - С. 5052.

Хирина, В. А. Материалы по питанию некоторых бентосоядных рыб в прибрежной зоне Черного моря у Карадага / В. А. Хирина // Труды Карадагской биологической станции АН УССР. - 1950. - Вып. 10. C. $53-65$.

Шварц, С. С. Метод морфофизиологических индикаторов в экологии наземных позвоночных / C. C. Шварц, В. С. Смирнов, Л. Н. Добринский // Труды Института экологии растений и животных. - 1968. Вып. 58. - 386 с.

Шульман, Г. Е. Физиолого-биохимические особенности годовых циклов рыб / Г. Е. Шульман. - Москва : Пищевая промышленность, 1972. - 368 с.

Экотоксикологические исследования прибрежной черноморской ихтиофауны в районе Севастополя. Москва : ГЕОС, 2016. - 360 с.

Ledoyer, M. Relation entre l'accroissemement nocturne massif de la faune vagile et les variations de la teneur en gaz dissous dans les herbiers de Posidonies superficiels / M. Ledoyer // C. r. Acad. sci. - 1961. Vol. 252. - P. 4207-4208. 
ВЕСТНИК ИБ КОМИ НЦ УрО РАН 2020 № 1

\section{MODERN DATA ON THE FOOD SPECTRUM OF THE BLACK SEA SCORPION FISH SCORPAENA PORCUS LINNAEUS, 1758}

V.A. Timofeev ${ }^{1}$, N.S. Kuzminova1, 2, L.V. Bondarenko', G.V. Kulikov ${ }^{2}$

${ }^{1}$ A. O. Kovalevsky Institute of Biology of the Southern Seas of the Russian Academy of Sciences, Sevastopol ${ }^{2}$ Sevastopol Center of Ecological and Naturalistic Study of Youth, Sevastopol

Summary. Assessment of the condition of adult specimens of the scorpion fish Scorpaena porcus Linnaeus, 1758 was carried out on individuals captured in the bays of Sevastopol (Balaklavskaya, Streletskaya, Sevastopolskaya and Karantinnaya) in 2017-2018. The increase in size-mass values with the age was found to be low or absent (especially for males), which indicates the poor feeding conditions in the period from 2012-2013 to the current time. At the same time, S. porcus from Sevastopolskaya Bay are under the best functional condition, which is expressed as a larger increase in size, weight and hepatosomatic index (HSI) of fish with age compared to those from other water areas. High values of condition factor and HSI of S. porcus caught in Balaklavskaya and Streletskaya bays are probably associated with the calorie content of the diet of scorpion. In winter, spring and autumn, Malacostraca predominate in the food clot of $S$. porcus (15, 19, and $14 \%$, respectively), and in summer - Pisces (14\%). In addition, in 2017-2018 the nutritional diversity of S. porcus has changed compared to the data of the last century and the beginning of the present century (including 2014). The changes of food spectrum of scorpion fish from Decapoda to smaller species of Malacostraca were probably due to acute decrease in the number of decapod crustaceans compared to the previous century.

Key words: scorpion fish, food spectrum, Black Sea, Sevastopol 